ISSN: 2146-3042

DOI: $10.25095 /$ mufad.827784

\title{
Konkordato Sürecinde Borca Batıklığın Tespiti ve Sonuçları Üzerine Bir Vaka Çalışması*
}

\author{
Ferhat BİTLISLİ** \\ Hakkı KIYMIK ***
}

\section{ÖZET}

Yürürlükten kaldırılan iflas ertelemenin yerini alan konkordato, borçlarını ödeyemeyecek durumda olan borçluların, borçlarının yeniden yapılandırılması anlamına gelmektedir. Iflas ertelemeden farklı olarak konkordatoda alacaklılar da söz sahibidir. Farklı sebeplerle konkordato başvurusu reddedilmiş olan borçlular için konkordato sürecinin iflasla sonuçlanması da muhtemeldir. Konkordatonun iflasla sonuçlanması için borçlunun borca batık olmasl gerekmektedir. Borca batıklı̆̆ın tespiti de konkordato komiser heyeti ya da muhasebe meslek mensubu bilirkişiler tarafindan hazırlanan rayici değer bilanço üzerinden yapılmaktadır. Çalışmada, konkordato komiser heyetinde bulunan mali üyeler veya muhasebe meslek mensubu bilirkişiler tarafindan borca batıklık bilançosunun oluşturulmasında dikkat edilmesi gereken hususlar tespit edilerek, konkordato sürecinde olan bir işletmenin borca batıklık bilançosunun oluşturulması ile ilgili bir vaka çalışması gerçekleştirilmiştir. Çalışmada, borca batıklık bilançosunun konkordato geçici mühleti içinde oluşturulması; işletme varlıklarının rayici değerlerinin klymet takdiri yapılarak yeniden hesaplanması ve borca batıklık bilançosu oluşturulurken özellikle dönem ayırıcı hesaplar ve avans hesapları kullanılarak aktifin olduğundan fazla gösterilmesine yönelik muhasebe manipülasyonlarına dikkat edilmesi gerektiği sonucuna ulaşılmıştır.

Anahtar Kelimeler: Borca batıklık, borca batıklık bilançosu, iflas erteleme, konkordato.

JEL Sinıflandırması: M41

\section{A Case Study on Detection and Results of Insolvency in the Concordat Process}

\section{ABSTRACT}

Concordat, which replaces the abolished bankruptcy postponement, means the restructuring of debts of debtors who are unable to pay their debts. Unlike postponing bankruptcy, creditors also have a say in concordat. It is also possible that the concordat process will result in bankruptcy for debtors whose concordat application has been rejected for different reasons. In order for the concordat to result in bankruptcy, the debtor must be over indebtedness. Detection of insolvency is also made on the current value balance sheet prepared by the concordat commissar committee or the professional accountant experts. In this study, a case study was carried out on creation of debt balance sheet of an enterprise that is in concordat process by determining the issues that need to be considered in creation of the balance sheet of insolvency by financial members or professional accountant experts in concordat commissar committee. In the study, it was concluded that the insolvency balance sheet should be formed within the temporary concordat, recalculating the fair values of business assets by appraising them and paying attention to accounting manipulations to overstate assets, especially by using period separator accounts and advance accounts while creating the balance sheet of insolvency.

Keywords: Insolvency, insolvency balance sheet, bankruptcy postponement, concordat.

Jel Classification: M41

\footnotetext{
* Makale Gönderim Tarihi: 18.11.2020, Makale Kabul Tarihi: 04.12.2020 , Makale Türü: Örnek Olay Çalışması

** Dr. Öğr. Üyesi, Burdur Mehmet Akif Ersoy Üniversitesi, Bucak Zeliha Tolunay Uygulamalı Teknoloji ve İşletmecilik Yüksekokulu, fbitlisli@mehmetakif.edu.tr, ORCID: 0000-0003-1638-8786.

*** Dr. Öğr. Üyesi, Burdur Mehmet Akif Ersoy Üniversitesi, Bucak Zeliha Tolunay Uygulamalı Teknoloji ve İşletmecilik Yüksekokulu, hkiymik@mehmetakif.edu.tr, ORCID: 0000-0002-4121-8060.
} 


\section{GİRIŞ}

Borca batıklık kavramı, gerek Türk Ticaret Kanunu (TTK) gerekse İcra ve İflas Kanunu (İK) bakımından sermaye kaybı olarak ifade edilmektedir (Ermenek vd., 2020: 1353). Kanun koyucu bu noktada borca batıklık durumunu, doğrudan doğruya iflas nedeni olarak düzenlemiş̧tir (TTK, md. 376; İ̈K md. 179). Ancak, borca batıklık halinde iflasın açılmasından önceki süreçte borçlunun veya alacaklının talebi ile konkordato yoluyla borçlunun finansal durumunun düzeltilerek borçlarının tasfiyesinin sağlanması mümkün kılınmıştır (Türk, 2004: 307). 6762 Sayılı Eski Türk Ticaret Kanunu ve 6102 Sayılı Türk Ticaret Kanunu ve 2004 sayılı İcra ve İflas Kanunun 179. maddesinde yer alan düzenlemelerle 2003 yilından beri uygulanmakta olan iflas erteleme, İIK'nın 179. maddesini değiştiren 28.02.2018 tarih ve 7101 sayılı kanunun 3. maddesindeki düzenleme ile yürürlükten kaldırılmıştır. İflasın ertelenmesi müessesinin kaldırılması ile birlikte 7101 sayılı kanunun 13. maddesi ile 2004 sayılı İIK'nun 285. maddesinde değişikliğe gidilerek kanunen var olan ancak uygulama imkânı bulunmayan konkordato müessesine yeniden işlerlik kazandırılmıştır (Bilen ve Güler, 2019: 81-82).

Konkordatoya ilişkin hükümlerde iflasın ertelenmesinden farklı olarak borca batık olma şartı bulunmamakla birlikte, borca batık olmayan ancak ilerleyen süreçte finansal zorlukla karşılaşma riski bulunan şahıs ve kurumların da konkordato hükümlerinden yararlanmasına olanak sağlanmıştır. Bu noktada, borca batıklık durumunun konkordato başvurusu açısından bir şart olmadığı görülmektedir (Demir ve Teker, 2019: 281). Ancak, geçici mühlet içerisinde konkordato ön projesinin uygulanabilirliği ile ilgili durumlar ve geçici mühlet sonunda kesin mühlet talebinin reddi, konkordato mühletinin kaldırlması, konkordato tasdik talebinin reddi ve konkordatonun bütün alacaklılar bakımından feshi hallerinde borca batıklık önem arz etmektedir. Sayılan bu durumların oluşması halinde işletmelerin borca batık olduğunun tespiti halinde mahkeme tarafindan iflasın açılması yükümlülüğü bulunmaktadır (ïIK, md. 292,308). $\mathrm{Bu}$ nedenle borca batıklık bilançosunun oluşturulması, doğuracağı sonuçlar bakımından konkordato komiser heyeti içinde yer alan mali konularla ilgili komisere veya mali komiserin bulunmadığı hallerde bilirkişi olarak görev alacak muhasebe meslek mensuplarına önemli sorumluklar yüklemektedir.

Çalışmada, konkordato geçici mühleti almış olan işletmelerin kaydi değer bilançolarının esas alınarak borca batıklık bilançosunun oluşturulmasında dikkat edilmesi gereken hususların tespit edilmesi amaçlanmıştır. Bu amaçla çalışmada, konkordato kurumu ile ilgili genel bilgiler verildikten sonra borca batıklığın, konkordatonun sonuçları açısından, önemine değinilmiş ve borca batıklık bilançosu oluşturulmasında dikkat edilmesi gereken hususlar, hesap gruplaritibariyle açıklanmıştır. Çalışmanın uygulama kısmında ise konkordato geçici mühleti almış olan bir işletmenin kaydi değer bilançosu esas alınarak borca batıklık bilançosu oluşturulmuştur.

\section{KAVRAMSAL ÇERÇEVE}

Çalışmanın bu kısmında, konkordatonun Türk Hukuk Sistemi içerisindeki yeri ve borca batıklık durumunun konkordatoya etkisi açıklanmıştır. 


\subsection{Türk Hukuk Sisteminde Konkordato}

Hukuki bir terim olan konkordato, dilimize İtalyancadan geçmiş olup aslı “concordato"dur. Konkordato kelimesi, hukuki bir terim olarak "anlaşmalı iflası" ifade etmektir. Konkordato, başka bir deyişle iflas durumunda alacaklıların, alacaklarını belli bir plana göre almaları için borçlu ile aralarında yaptıkları sözleşmedir (www.sozluk.gov.tr, 2020).

İcra ve İflas Kanunu'nun 285. maddesinde “Borçlarını, vadesi geldiği hâlde ödeyemeyen veya vadesinde ödeyememe tehlikesi altında bulunan herhangi bir borçlu, vade verilmek veya tenzilat yapılmak suretiyle borçlarını ödeyebilmek veya muhtemel bir iflâstan kurtulmak için konkordato talep edebilir. Iflâs talebinde bulunabilecek her alacakl, gerekçeli bir dilekçeyle, borçlu hakkında konkordato işlemlerinin başlatılmasını isteyebilir" denilmektedir (İ̈K, md. 285). İcra ve İflas Kanunu'nda belirtilen bu koşulların meydana gelmesi halinde konkordato, borçlarını ödeyemeyecek hale gelen borçlunun iflastan kurtulabilmesi için uygulanan hafifletilmiş bir icra kurumudur. Başka bir ifadeyle konkordato, iflasa yaklaşan, özel ve hafifletilmiş bir cebri icra türü ve kolektif bir tasfiye şeklidir (Karacan, 2018: 98).

İcra ve İflas Kanununa göre konkordatonun, “Adi Konkordato", "Mal Varlığının Terki Suretiyle Konkordato" ve "İflastan Sonra Konkordato" olmak üzere 3 türü bulunmaktadır.

- “Adi Konkordato”, iflasa tabi olan ve olmayan borçlular için uygulama alanı bulmaktadır. Konkordato teklifi, borçludan gelebildiği gibi alacaklılardan da gelebilmektedir. $\mathrm{Bu}$ konkordato türünde borçlu, iflasa yakın ise konkordato süreci ile iflastan kurtulabilmektedir. Bu özelliğinden dolayı adi konkordato, iflas önleyici konkordato olarak da adlandırılmaktadır.

- "Malvarlığının Terki Suretiyle Konkordato", alacaklılara, borçlunun malvarlığı üzerinde tasarruf etme veya bu malların tamamını ya da bir kısmını üçüncü kişiye devretme yetkisi verir. $\mathrm{Bu}$ yöntem ile alacaklı taraflar kendilerine terk edilen malvarlığını tasfiye ederek alacaklarını tahsil ederler (Akdeniz ve Kayıhan, 2019: 193). Konkordatonun bu türünde borçlunun ticari hayatına tekrar dönmesi mümkün bulunmamaktadır. Çünkü borçlu, alacaklıların alacaklarını alabilmesi için tüm malvarlığını alacaklılara terk etmektedir (Eroğlu, 2018: 26).

- “İflastan Sonra Konkordato", bir diğer adıyla iflas içi konkordato ise halihazırda iflasına karar verilmiş olan borçluların, iflas süreci devam ederken, iflastan ve iflasın kamu hukuku bakımından etkilerinden kurtulmak için teklif ettikleri konkordato türüdür (Özdemir, 2019: 19) Talep edilen konkordato, kabul edilip onaylanırsa borçlu hakkındaki iflas, bütün hüküm ve sonuçlarıyla kaldırılır. İflas eden borçlu, (müflis) iflas tasfiyesi sürecindeki konkordato teklifini iflas idaresine bildirir. Konkordatonun hükümleri, konkordato kararının kesinleşmesi ile değil, iflasın kaldırılması ile yürürlüğe girer. İflas konkordatosu, aksi bir durum olmadığı müddetçe adi konkordato hükümlerine tabidir (Ermenek vd., 2020: 13641365). 


\subsection{Türk Ticaret Kanunu ve İcra İflas Kanunu Açısından Borca Batıklık ve Konkordato}

6102 sayılı TTK'nın 376/3. maddesinde, borca batıklıklığa ilişkin olarak şirket yönetim kurulu tarafından işletmenin devamlılığı esasına göre ve muhtemel satı̧̧ fiyatları üzerinden oluşturulan ara bilançoda şirket aktiflerinin şirket alacaklılarının alacaklarını karşılamaya yetmediğinin anlaşılması halinde şirket yönetimine şirketin iflasını isteme yükümlülüğü getirmiştir. İlgili maddeden borca batıklığın şirket varlıklarının şirket borçlarını karşılamaması durumunun TTK açısından borca batıklık olarak nitelendirildiği anlaşılmaktadır (Kayar, 2012: 644). Yine IIIK'nın 179. maddesinde "Sermaye şirketleri ile kooperatiflerin, aktiflerin muhtemel satıs fiyatları üzerinden düzenlenen ara bilançoya göre borca batık olduğu idare ve temsil ile vazifelendirilmiş kimseler veya şirket ya da kooperatif tasfiye hâlinde ise tasfiye memurları veya bir alacakl tarafindan beyan ve mahkemece tespit edilirse, önceden takibe hacet kalmaksızın bunların iflâsına karar verilir." denilmek suretiyle TTK'ya paralellik gösteren bir şekilde borca batıklık kavramından bahsedilmiş̧tir. Bu noktada TTK'nın 376/3. maddesinde de belirtilen borca batıklık durumu, TTK'nın 376/1-2. maddelerinde belirtilen sermaye kaybının son yıllık bilançodan anlaşılması kavramından farklı olarak, işletmenin devamlılı̆̆ ve muhtemel satış fiyatları üzerinden hazırlanan ara bilanço kavramı ile açıklanmaktadır (Altay, 2016: 32).

Borca batıklık, 6102 sayılı TTK'nın 377. maddesinde “Yönetim kurulu veya herhangi bir alacakll, 376'ncı maddenin üçüncü fikrası uyarınca yapacağı iflâs talebiyle birlikte veya bu kapsamda yapılan iflâs yargılaması sırasında 2004 sayılı Kanunun 285 inci ve devamı maddeleri uyarınca konkordato da talep edebilir" denilmektedir. Yine İIK'nın 179. maddesinde “.... Türk Ticaret Kanunu'nun 377'nci ve 634'üncü maddeleri ile 24/4/1969 tarihli ve 1163 sayll Kooperatifler Kanunu'nun 63'üncü maddesi hükmü saklıdır" denilmek suretiyle her iki kanunla borca batıklı̆ğı özel bir konkordato nedeni olarak düzenlendiği görülmektedir (Apal1, 2018: 214).

İIK'nın.285'inci maddesine göre; borçlunun, vadesi gelmiş borçlarını ödeyememesi, vadesinde ödeyememe tehlikesi altında bulunması ve iflasa tabi olan tacirlerin borca batık olması, konkordato sebebi olarak gösterilebilmektedir. Konkordato talebinde, borca batıklık ve borçlarını vadesinde ödeyememe ihtimali, bir konkordato nedeni olarak gösterilse de iflas erteleme taleplerinden farklı olarak borca batıklık bir şart olarak düzenlemelerde yer almamaktadır (Oruç, 2018: 4). İşletmelerin konkordato taleplerinde, borca batık olup olmamalarının etkisi konkordato süreci içerisindeki gelişmelere bağlı olarak sonuç doğurmaktadır. Borçlunun konkordato talebinden feragat etmesi, mahkemenin tasdik talebini reddetmesi veya konkordatoyu tamamen feshetmesi durumlarında, borçlunun borca batık olduğunun tespiti halinde mahkemece resen iflasın açılmasına karar verilecektir. İflas davalarının çekişmesiz olması ve kamu düzenini ilgilendirmesi sebebiyle konkordato geçici mühlet talebinin reddi halinde dahi mahkeme tarafından talep, iflasın açılması koşulu olarak değerlendirilerek borca batıklı̆̆ın tespiti halinde iflasın açılmasına karar verilecektir (Akil, 2019: 132).

Bahsi geçen nedenlerle borca batıklı̆ı̆ın tespiti gerek borçlu, gerek alacaklılar, gerekse kamu düzenini ilgilendirmesi bakımından önemli sonuçlar doğurmaktadır. Dolayısıyla borca batıklığın tespiti büyük önem arz etmektedir (Altay, 2016: 53). Uygulamada, borçlu şirketler tarafından konkordato ön projesi ekinde yer alan borca batıklı̆ga ilişkin tespitlerin, geçici 
mühlet talebinde, kesin mühlet talebinde, konkordatonun feragatı ve feshi hallerinde dikkate alınmadığı, borca batıklık hesaplamasının söz konusu aşamalarda konkordato komiser heyeti tarafından yapıldığı, komiser heyetinin sayısı ve uzmanlık alanının yetersiz kalması halinde bilirkişi incelemesi neticesinde oluşturulan borca batıklık bilançosunun dikkate alınarak karar verildiği görülmektedir (Budak ve Kale, 2019: 14). İIK'nın 287. maddesi gereği, "Mahkeme, geçici mühlet kararıyla birlikte konkordatonun başarıya ulaşmasının mümkün olup olmadı̆̆ının yakından incelenmesi amacıyla bir geçici konkordato komiseri görevlendirir. Alacaklı sayısı ve alacak miktarl dikkate alınarak gerektiğinde üç komiser de görevlendirilebilir. Üç komiser görevlendirilmesi durumunda komiserlerden biri, mahkemenin bulunduğu ilde faaliyet göstermek şartıyla Kamu Gözetimi, Muhasebe ve Denetim Standartlar Kurumu tarafindan yetkilendirilmiş bağımsız denetçiler arasından seçilir." Mahkeme tarafindan 3 komiser görevlendirilmesi durumunda komiserlerden birisinin muhasebe ve finans ile ilgili kişilerden olması sebebi ile borca batıklık bilançosu bu komiser tarafindan oluşturabilmektedir. Tek komiser atanması halinde komiserin uzmanlığının uyuşmaması durumunda borca batıklık bilançosunun oluşturulması bilirkişiler aracılığı ile yapılmaktadır (Şengöz ve Ayaz, 2020: 125).

İIK'nın 286/b maddesinde, konkordato talebine eklenecek belgeler arasında hem işletmenin devamlılığı esasına göre hem de aktiflerin muhtemel satış fiyatları üzerinden hazırlanan ara bilançoların sunulması gerektiği belirtilmiştir (Çukacı, 2019: 52). İşletmenin devamlılığı esasına göre düzenlenen bilanço, işletmenin faaliyetlerinin sürdürülmesi durumunda, yani hem bilançonun oluşturulduğu tarihte hem de gelecekteki bir zaman zarfında işletme faaliyetlerinin sonuçları değerlendirilmek sureti ile oluşturulmaktadır. İşletmenin devamlılığı esası, sadece değerlemenin yapıldığı zamanı değil, gerçekçi varsayımlara dayalı olarak ileride oluşabilecek değerin de göz önünde bulundurulmasını gerektirmektedir. Bunun için aktifler, borçlar, gelir-gider ile işletmenin elde edeceği firsatlar, ihtimallere göre hesaba katılarak değerlendirilir. Aktif ve pasiflerin işletmenin sürekliliğine göre değerlendirilmesi, yukarıda da belirtildiği gibi, faaliyetine devam edecek bir işletme esas alınarak değerlendirme yapılması anlamına gelmektedir. İşletmenin devamlılığına ilişkin olarak düzenlenen bilançolar, konkordato ön projesini destekleme noktasında önem arz etmektedir (Özbilen, 2015).

Aktiflerin gerçek değerleri esasına göre düzenlenen bilanço ise aktiflerin defter değerlerine göre değil, piyasada oluşan gerçek değerlerinin belirlenmesi sureti ile oluşturulan bilançodur. Bu sebeple ara bilanço çıkarılırken yıllık bilançoda olduğu gibi kayıtlı değerler esas alınmaz. Aktiflerin rayiç değerleri esasına göre düzenlenen ara bilançonun temel amacı, şirket aktifinin rayiç değerini gerçekçi bir biçimde ortaya koyarak aktiflerin borçları karşılama noktasında yeterli olup olmadığının tespitine imkan sağlamaktır. Borca batıklığın tespitinde aktiflerin gerçek değerini göstermesi ve sübjektif değerler içermemesi sebebi ile aktiflerin rayici değerine göre hazırlanan bilançonun oluşturulması daha sağlıklı sonuçlar doğuracaktır (Özbilen, 2015). Her ne kadar konkordato talebinde aktiflerin rayici değerlerine ilişkin bilanço sunulsa da, mahkeme tarafından konkordato talebinin çeşitli sonuçlarına kaynak oluşturması bakımından komiser heyeti veya bilirkişi heyetlerinden borca batıklık tespitine yönelik rapor istenmektedir.

Çalışmanın bundan sonraki kısmında hukuki değerlendirmeden ziyade muhasebe tekniği açısından borca batıklık bilançosunun oluşturulmasındaki ilkeler ve özellik arz eden durumlar muhasebe bakış açısı ile değerlendirilmiştir. 


\section{BORCA BATIKLIK BİLANÇOSUNUN OLUŞTURULMA İLKELERİ}

Borca batıklık kavramının, konkordato süreci içerisinde geçici mühlet talebinin reddi, kesin mühlet talebinin reddi, konkordato talebinden feragat ve konkordatonun feshi durumlarında mahkeme tarafindan doğrudan değerlendirmeye alınan ve şirketin iflası ile sonuçlanacak kararlara etki eden bir husus olduğu önceki bölümlerde ayrıntılı olarak açıklanmıştır. Çalışmanın bu kısmında, borca batıklığın tespitine yönelik olarak gerek konkordato ön projesi hazırlama noktasındaki bağımsız denetim kuruluşları, gerekse konkordato sürecinin çeşitli aşamalarında borca batıklık bilançosu oluşturması gereken konkordato komiseri olarak görev yapan muhasebe meslek mensupları ve bilirkişilerin borca batıklık bilançosunun düzenlenmesi aşamasında dikkat etmesi gereken hususlar tespit edilmiştir.

Borca batıklığın tespiti için düzenlenen bilançonun, aktiflerin muhtemel satış fiyatları üzerinden hazırlanan bilanço olması gerekmektedir. Rayici değer bilançosu olarak da ifade edilebilecek bu bilanço, düzenleme ilkeleri bakımından yıllık bilanço ile bir farklılık göstermemektedir. Rayici değer bilançosunun oluşturulmasında, yıllık bilançodan farklı olarak şirketin varlıkları ve borçlarının gerçek değerleri, somut delillere dayalı olarak tespit edilmektedir. $\mathrm{Bu}$ sebeple rayici değer bilançosu oluşturulurken, mali nitelikteki işlemlerin belgelere dayalı olarak kaydedildiği düşünüldüğünde, bilançoyu oluşturan unsurlara ilişkin olarak ticari defter ve belgelerin detaylı olarak incelenmesi gerekmektedir. Bu noktada özellikle şirketin hayali cari hesap şeklinde borçlar yaratıp yaratmadığı, hayali alacak ve varlık yaratmak sureti ile olası bir konkordato talebinde borca batıklığın önüne geçilip geçilmediği ve hesap detaylarını kapatacak şekilde torba hesaplar kullanıp kullanmadığı vb. hususların ayrıntılı olarak incelenmesi ve analiz edilmesi gerekmektedir. Dolayısıyla ilgililerin TDHP'de yer alan varlık ve kaynak kalemlerine ilişkin olarak Tablo 1'de yer alan değerlendirmeleri yapması, borca batıklığın tespiti açısından önem arz etmektedir.

Tablo 1. Borca Batıklık Bilançosunun Oluşturulmasında Dikkat Edilmesi Gereken Hususlar

\begin{tabular}{|l|l|}
\hline HESAP GRUBU & \multicolumn{1}{|c|}{ AÇIKLAMA } \\
\hline Hazır Değerler & $\begin{array}{l}\text { Nakit ve nakit benzeri kalemler fiili sayım yapılarak, mukayyet değerleri } \\
\text { üzerinden değerlendirmeye alınır. Nakit ve benzeri kalemler içerisinde döviz } \\
\text { cinsinden varlıklar var ise borca batılık değerleme tarihindeki TCMB } \\
\text { tarafından açılanan döviz ve efektif alış kuru üzerinden değerlenir. }\end{array}$ \\
\hline Menkul Kıymetler & $\begin{array}{l}\text { Menkul kıymet kalemi borsada işlem görüyor ise bilanço düzenlenen tarihteki } \\
\text { borsa rayicinden, borsa rayici bulunmayan menkul kiymet kalemleri ise } \\
\text { piyasada oluşan değeri üzerinden değerlenir. Değerleme yapılması sebebiyle } \\
\text { menkul kıymet değer düşüklüğ̈ karş1lığ kalemi, gerçek borç niteliği taşımadığı } \\
\text { için bilanço dışı tutulur. }\end{array}$ \\
\hline
\end{tabular}




\begin{tabular}{|c|c|}
\hline Ticari Alacaklar & $\begin{array}{l}\text { Alacak tutarlarının tahsil edilebilirliğine ilişkin değerlendirmenin yapılması ve } \\
\text { tahsil imkanı bulunmayan alacak kalemlerinin bilanço dışı tutulması } \\
\text { gerekmektedir. Şüpheli hale gelmiş ticari alacak kalemleri bilanço dişı tutulur. } \\
\text { Şüpheli alacağa ilişkin olarak ayrılan karşılık kalemleri bilanço dışı tutulur. } \\
\text { Senetli alacaklar tasarruf değerleri ile bilançoda gösterilir. Verilen depozito ve } \\
\text { teminatlar tahsil edilebileceği tutarlar üzerinden bilançoya aktarılmalıdır. Borçlu } \\
\text { işletmenin varlıklarını olduğundan fazla gösterebilmek amacıyla yapay } \\
\text { alacaklılar oluşturması ihtimali göz önünde bulundurularak gerekli } \\
\text { incelemelerin yapılması gerekmektedir. }\end{array}$ \\
\hline Diğer Alacaklar & $\begin{array}{l}\text { Tahsil edilebilme olanağı tespit edilir. Yine alacağın varlığına ilişkin inceleme } \\
\text { yapılmak sureti ile değerlendirmeye tabi tutulur. }\end{array}$ \\
\hline Stoklar & $\begin{array}{l}\text { Stoklara ilişkin envanter listeleri oluşturulur. Bu noktada şirketin şube ve } \\
\text { depolarına ilişkin tespitlerin komiser heyetinde bulunan alanında uzman } \\
\text { komiser veya komiser heyeti dişından görevlendirilecek bilirkişi tarafından } \\
\text { yapılması önem arz etmektedir. Listelerin oluşturulması sırasında konsinye } \\
\text { nitelikte stok olup olmamasına ilişkin çalışma yapılmalıdır. İşletmede yer alan } \\
\text { konsinye stoklar değerleme dışı tutulmalıdır. Yine işletmeye ait başka } \\
\text { işletmelerde yer alan konsinye stoklar envanter işlemine dahil edilmelidir. } \\
\text { Envanter listelerinin oluşturulmasından sonraki süreçte stokların satılabilme } \\
\text { durumları tespit edilir. Satılabilme özelliği olmayan stok kalemleri bilançoda } \\
\text { gösterilmez. Yarı mamuller mevcut haliyle satılabilme veya mamule } \\
\text { dönüşsebilme durumlarına göre değerlendirmeye tabi tutulur. Verilen sipariş } \\
\text { avansları ise detaylı inceleme konusu yapılarak bilançoya dahil edilmeli ve } \\
\text { tevsik edici belge ve mutabakat sağlanmalıdır. Değer düşüklüğüne ilişkin } \\
\text { karşılıklar bilanço dışı tutulur. }\end{array}$ \\
\hline $\begin{array}{l}\text { Yıllara Yaygın Ínşaat ve } \\
\text { Onarım Maliyetleri }\end{array}$ & $\begin{array}{l}\text { Y1llara yaygın inşaat ve onarım maliyetleri hesabı gerçek bir varlık unsuru } \\
\text { olmaması sebebiyle bilanço dışı tutulur. Ancak hesap içerisinde yüklenilen işe } \\
\text { ilişkin satılabilir madde ve malzeme ve bilanço tarihine kadar tahakkuk etmiş } \\
\text { ancak tahsil edilmemiş hakkedişler var ise bilançoda gösterilir. Ayrıca bu } \\
\text { hesapla bağı bulunan taşeronlara verilen avanslar hesabı da borca batıklık } \\
\text { bilançosunda defter değeriyle yer almalıdır. }\end{array}$ \\
\hline $\begin{array}{l}\text { Gelecek Aylara/Yıllara } \\
\text { Ait Giderler ve Gelir } \\
\text { Tahakkukları }\end{array}$ & $\begin{array}{l}\text { "Gelecek Aylara/Yıllara Ait Giderler" hesabı, muhasebe tekniği bakımından } \\
\text { oluşturulan hesaplar olması sebebi ile gerçek bir aktif değer oluşturmaz. Bu } \\
\text { nedenle bilanço dışı tutulmalıdır. Gelir tahakkukları ile ilgili olarak alacak } \\
\text { niteliği taşı öza olliğine ilişkin tespitler yapıldıktan sonra bilançoda } \\
\text { gösterilmeli ve gerekli hususlar bilanço dipnotlarında açıklanmalıdır. }\end{array}$ \\
\hline Diğer Dönen Varlıklar & $\begin{array}{l}\text { Katma Değer Vergisi'ne ve avanslara ilişkin hesaplar kayıtlı değerleri ile } \\
\text { bilançoda gösterilir. Sayım ve Tesellüm Noksanları hesabı ise geçici bir hesap } \\
\text { olduğu ve alacak unsuru oluşturmadığından bilançoda gösterilmez. Diğer çeşitli } \\
\text { dönen varlıklar hesabında gerekli doğrulamalar yapılar kayıtlı değerleri ile } \\
\text { bilançoda gösterimi sağlanmalıdır. Bu grupta yer alan karşılık hesabı da gerçek } \\
\text { bir borç niteliği taşımadığı için bilanço da yer almamalıdır. }\end{array}$ \\
\hline Mali Duran Varlıklar & $\begin{array}{l}\text { Ortak olunan şirket borsada işlem görmesi halinde borsa rayici ile şirketin } \\
\text { borsada işlem görmemesi halinde bilirkişi incelemesine ilişkin olarak tespit } \\
\text { edilen değerle üzerinde bilançoda yer almalıdır. İlgili ortaklıklara ilişkin olarak } \\
\text { işletme tarafında yapılan sermaye taahhütleri ise işletmenin borcu olarak } \\
\text { değerlendirmeli ve bilançoda kayıtlı değerleri ile gösterilmelidir. }\end{array}$ \\
\hline $\begin{array}{l}\text { Maddi Duran } \\
\text { Varlıklar }\end{array}$ & $\begin{array}{l}\text { Gerek geçici mühlet süreci gerekse kesin mühlet süreci içinde alanında uzman } \\
\text { bilirkişiler tarafindan yapılan kıymet takdiri tutarları üzerinde bilançoda } \\
\text { gösterilmelidir. İşletme tarafından ilgili maddi duran varlık kalemlerine ilişkin } \\
\text { olarak ayrılan amortisman tutarları bilançoda yer almamalıdır. Yapılmakta olan } \\
\text { yatırımlar hesabı rayiç bedelleri ile verilen avanslar kayıtlı değerleriyle borca } \\
\text { batıklık bilançosunda yer alır. }\end{array}$ \\
\hline $\begin{array}{l}\text { Maddi Olmayan } \\
\text { Duran Varlıklar }\end{array}$ & $\begin{array}{l}\text { Kullanım hakkı tescile tabi olan patent ve marka gibi varlıklarda tescil } \\
\text { belgelerinin tespiti yapılmalıdır. Tescil belgesi bulunan patent ve markalara } \\
\text { bilançoda yer verilmelidir. Markalara ilişkin değer tespitinin yapılması } \\
\text { gerekmektedir. Değer tespiti yapılan marka ve patentler değerleme sonucunda } \\
\text { oluşan değeri üzerinden bilançoda gösterilmelidir. Verilen avanslar, kayıtlı }\end{array}$ \\
\hline
\end{tabular}




\begin{tabular}{|c|c|}
\hline & $\begin{array}{l}\text { değerleri ile diğer maddi olmayan duran varlıklar ise içeriği dipnotlarda } \\
\text { açıklanarak bilirkişilerce tespit edilen piyasa değerleriyle borca batıktık } \\
\text { bilançosunda yer alır. }\end{array}$ \\
\hline $\begin{array}{l}\text { Özel Tükenmeye Tabi } \\
\text { Varlıklar }\end{array}$ & $\begin{array}{l}\text { Verilen avanslar kayıtlı değerleriyle borca batıklık bilançosunda yer alır. Arama } \\
\text { giderleri, hazırlık ve geliştirme giderleri, diğer özel tükenmeye tabi varlıklar ve } \\
\text { birikmiş tükenme payları hesapları borca batıklık bilançosunda yer almaz. }\end{array}$ \\
\hline Mali Borçlar & $\begin{array}{l}\text { Finansal kiralama işlemlerine ilişkin borçlar gerekli hesaplamalar yapıldıktan } \\
\text { sonra bulunan değeriyle bilançoda yer alır. Uzun vadeli kredilerin anapara ve } \\
\text { faizleri, tahvil anapara ve borç taksit faizleri, çıarılmış bonolar ve senetler, } \\
\text { çıarılmış diğer menkul kıymetler ve diğer mali borçlar hesapları da gerekli } \\
\text { incelemeler yapıldıktan sonra kayıtlı değerleriyle gösterilirler. Ayrıca menkul } \\
\text { kıymet ihraç farkları hesabı ise borca batıklık bilançosunda yer almamalıdır. } \\
\text { Kesin mühlet içerisinde ya da tasdike esas borca batıklı̆̆ın tespitinde ise ilgili } \\
\text { bankaların alacak bildirimleri ve borçlunun kabulünde bulunan borç tutarları ile } \\
\text { kaydi bilanço karşılaştırılarak gerekli düzeltmelerin de yapılması } \\
\text { gerekmektedir. }\end{array}$ \\
\hline Ticari Borçlar & $\begin{array}{l}\text { Ticari borç kalemleri teyit edilmek sureti kayıtlı değerleri ile bilançoda } \\
\text { gösterilmelidir. Yine borç senetlerine ilişkin olarak reeskont hesaplaması } \\
\text { yapılmak sureti ile bilanço günündeki değeri tespit edilmeli ve bilançoda ayrı } \\
\text { bir hesap kalemi olarak gösterilmelidir. Kesin mühlet içerisinde ya da tasdike } \\
\text { esas borca batıklığın tespitinde ise ilgili alacaklıların alacak bildirimleri ve } \\
\text { borçlunun kabulünde bulunan borç tutarları ile kaydi bilanço karşılaştırılarak } \\
\text { gerekli düzeltmelerin de yapılması gerekmektedir. Konkordato geçici mühleti } \\
\text { sonrası ortaya çıkan borçların alacak müzakere toplantısında, konkordatoya tâbi } \\
\text { borç tutarına dahil olmaması ve teminata tâbi olması sebebiyle "geçici mühlet } \\
\text { sonrası ortaya çıkan borçlar" alt hesabında ayrıca izlenmesi gerekir. }\end{array}$ \\
\hline Diğer Borçlar & $\begin{array}{l}\text { Diğer borçlar grubu içerisinde borç senedi bulunması halinde reeskonta tabi } \\
\text { tutulmak sureti bilançoda yer almalıdır. Ortaklara Borçlar, İştiraklere Borçlar, } \\
\text { Bağlı Ortaklıklara Borçlar, Personele Borçlar ve Diğer Çeşitli Borçlar hesapları } \\
\text { ise borca batıklık bilançosuna kayıtlı degerleriyle aktarılır. }\end{array}$ \\
\hline Alınan Avanslar & $\begin{array}{l}\text { Alınan Sipariş Avansları ve Alınan Diğer Avanslar hesap kalemleri borca atıklık } \\
\text { bilançosuna aktarılırken kayıtlı değerleri üzerinden aktarılırlar. }\end{array}$ \\
\hline $\begin{array}{l}\text { Yıllara Yaygın İnşaat } \\
\text { ve Onarım Hakedişleri }\end{array}$ & Bir borç unsuru olmadığından borca batıklık bilançosunda yer almaz. \\
\hline $\begin{array}{l}\text { Ödenecek Vergi ve } \\
\text { Diğer Yükümlülükler }\end{array}$ & Borç niteliği taşıdıklarından tamamı bilançoda yer alır. \\
\hline $\begin{array}{l}\text { Borç ve Gider } \\
\text { Karşılıkları }\end{array}$ & $\begin{array}{l}\text { Dönem Karı Vergi ve Diğer Yasal Yükümlülükler Karşılıkları ve Dönem } \\
\text { Karının Peşin Ödenen Vergi ve Diğer Yükümlülükleri hesapları borca batıklık } \\
\text { bilançosuna kayıtlı değerleri ile gösterilir. Kıdem Tazminatı Karşılığı, Maliyet } \\
\text { Giderleri Karşılığı ve Diğer Borç ve Gider Karşılıkları hesapları ise hesaplama } \\
\text { yapılarak bilançoda gösterilir. Bu hesaplamalara ilişkin bilanço dipnotlarında } \\
\text { bilgi verilmelidir. Ayrıca uzun vadeli yabancı kaynaklar altında yer alan borç ve } \\
\text { gider karşılıkları hesap grubu altındaki hesaplar ise borca batıklık bilançosuna } \\
\text { kayıtlı değerleriyle aktarılır. }\end{array}$ \\
\hline $\begin{array}{l}\text { Gelecek Aylara Ait } \\
\text { Gelirler ve Gider } \\
\text { Tahakkukları }\end{array}$ & $\begin{array}{l}\text { Gelecek aylara/yıllara ait gelirler hesabı borca batıklı önceki süreçte tutarları } \\
\text { işletme tarafından peşin tahsil edilen değerlerin muhasebeleştirildiği bir hesap } \\
\text { kalemi olması sebebi ile bilançoda yer verilmemelidir. Yine kısa vadeli yabancı } \\
\text { kaynaklarda ve uzun vadeli yabancı kaynaklarda yer alan gider tahakkukları } \\
\text { hesapları ise kayıtlı değerleri üzerinden borca batıklık bilançosunda } \\
\text { gösterilmelidir. }\end{array}$ \\
\hline $\begin{array}{l}\text { Diğer Kısa/Uzun } \\
\text { Vadeli Yabancı } \\
\text { Kaynaklar }\end{array}$ & $\begin{array}{l}\text { Sayım ve tesellüm fazlalığı hesapları işletme açısından bir borç unsuru } \\
\text { oluşturmadığı için bilançoda gösterilmez. Diğer kalemler ise kayıtlı değerleriyle } \\
\text { bilançoda yer alır. Diğger uzun vadeli yabancı kaynaklar hesap grubunda yer alan } \\
\text { hesaplar ise kayıtlı değerleriyle borca batıklık bilançosunda yer alır. }\end{array}$ \\
\hline
\end{tabular}

Kaynak: Bitlisli ve Y1lmaz, 2016:212-215; Y1lmaz, 2009: 155-218.

Uygulamada, konkordato talep eden bazı şirketlerin ortaklardan alacaklar hesabını alacak senetlerine dönüştürdügü, karmaşık ve envanter işlemi güç olan işletmelerde fiktif stok 
kalemleri yaratıldı̆̆ı, gelecek aylara/yıllara ait gider ve gelir tahakkukları hesaplarının amacı dışında kullanıldığı ve bu şekilde aktif yapının büyütülerek olası bir iflas durumunun önüne geçilebildiği görülmektedir. Bunun dışında, şirket borçlarına ilişkin olarak kesin mühletin alınmasından sonraki süreçte, farklı sebeplerle konkordatonun reddi halinde düzenlenecek borca batıklık bilançolarında, ilgililerin kesin mühlet içerisindeki alacak bildirimindeki ve borçlunun kabulünde bulunan tutarların dikkate alması gerektiği düşünülmektedir. Zira alacak bildirimleri, adi alacak yönünden kesin mühlet kararının verildiği tarihe kadar faiz işletilmek sureti ile bildirilmektedir. Bu nedenle kesin mühlet içinde veya kesin mühletin kaldırılmasına bağlı olarak mahkeme tarafından borca batıklığın tespitine yönelik yapılacak taleplerde ilgili tutarların alacak bildirimi üzerindeki ve borçlunun kabulündeki tutarlar üzerinden değerlendirilmesi daha doğru sonuçlar verecektir. Yine muhasebe uygulamalarında fatura ve herhangi bir belgeye dayanmayan işlemler için kullanılmakta olan, alınan ve verilen sipariş avanslarına ilişkin olarak değerlendirmenin titizlikle yapılması gerekmektedir. Özellikle alınan sipariş avansları hesabı ile ilgili yapay alacaklı oluşturmak sureti ile konkordato nisabı üzerinde manipülasyon yapıldığı görülmektedir. Burada konkordato nisabı, konkordatoya tâbi olup konkordato alacak müzakere toplantısına konu edilen borç tutarını ifade etmektedir (Kale, 2018:245-249). İİK'ya göre konkordatonun tasdik şartlarından bir tanesi de konkordato projesinin konkordatoya tâbi alacaklılar tarafından belirli oranda kabul edilmiş olmasıdır. Kanuna göre "konkordato projesi; kaydedilmiş olan alacaklıların ve alacakların yarısını veya kaydedilmiş olan alacaklıların dörtte birini ve alacakların üçte ikisini, aşan bir çoğunluk tarafindan imza edilmiş ise kabul edilmiş sayılır" (İ̈K, md.302). Bu sebeple, oluşturulan yapay alacaklılardan alınan kabul oyları, konkordatonun tasdiki için gerekli olan kabul şartını yerine getirmek adına borçluya avantaj sağlamış olacaktır. Bu bakımdan, bu hesaplara ilişkin olarak banka dekontu vb tevsik edici belgelerin varlığı aranmalıdır.

Borca batıklık bilançosu oluşturulurken öz kaynaklar kalemine bilançoda yer verilip verilmemesi konusunda iki farklı görüş vardır. Bunlardan ilki bilanço denkliğinin sağlanabilmesi için öz kaynakların bilançonun pasifinde tek tek gösterilmesi, ikincisi ise öz kaynak kaleminin bilançoda yer almaması gerektiği görüşüdür (Keleş, 2017: 194). Her iki durumda da borca batıklık bilançosu oluşturulurken borçlu şirketin öz varlığının temel muhasebe denkliği göz önünde bulundurularak hesaplanması gerekmektedir.

\section{BORCA BATIKLIK BIILANÇOSUNUN OLUŞTURULMASINA İLIŞKINN VAKA ÇALIŞMASI}

Çalışmanın bu bölümünde, konkordato geçici mühlet talebinde bulunan bir sermaye şirketinin mahkemeye sunmuş olduğu ara bilançosunda yer alan varlık ve yabancı kaynak kalemlerinin satış değerleri (rayici) üzerinden borca batıklık bilançosunun oluşturulması ve konkordato talebinde sunulan ara bilanço ile karşılaştırılması yapılacaktır. 30.01.2019 tarihli 30671 sayılı Resmi Gazetede yayımlanan Konkordato Talebine Eklenecek Belgeler Hakkında Yönetmeliğin 7. maddesine göre, konkordato ön projesine eklenen finansal tabloların hesap dönemi kapanışı üzerinden, konkordato başvuru tarihi itibariyle bir takvim yılı geçmemiş olması gerekmektedir. Bu sebeple bazı durumlarda borçlular tarafından mahkemeye sunulan finansal tablolar başvuru tarihinden önceki 1 yılı kapsayabilmektedir. Bu durum, finansal tablonun oluşturulduğu tarihten geçici mühlet başvurusuna kadar geçen süredeki finansal olayların kapsam dışında kalmasına sebep olmaktadır. Bu nedenle, komiser heyetinin az yukarıda esasları belirtilen hususlara dikkat etmek kaydıyla finansal tabloları geçici mühlet kararının verildiği tarihe göre güncellemesi gerekmektedir. $\mathrm{Bu}$ durum, konkordato 
kapsamındaki borçların ayırt edilmesi noktasında da önem arz etmektedir. Bunun yansıra geçici mühlet kararının verilmesi ile birlikte konkordato kapsamında yer alan borç tutarlarının geçici mühlet tarihi itibari ile ayrı hesaplarda takip edilmesi konkordato alacak toplantısında nisabın belirlenmesi ve konkordato geçici mühlet ve kesin mühlet sürecinde oluşan konkordato kapsamında yer almayan borçların belirlenmesi ve teminat tutarlarının hesaplanması açısından önem arz edecektir.

\section{1. Çalışmanın Amacı ve Yöntemi}

Çalışmanın amacı, konkordato geçici mühlet talebinde bulunan işletmelerin konkordato sürecinin seyrine bağlı olarak konkordato başvurusunun olası reddi durumunda, mahkemenin iflasın açılmasına karar vermesi bakımından son derece önemli olan borca batıklık bilançosunun oluşturulmasında dikkat edilmesi gereken hususların belirlenmesidir. $\mathrm{Bu}$ amaçla çalışmada konkordato geçici mühlet başvurusunda bulunmuş olan bir işletmenin kaydi değer bilançosu esas alınarak satış değerleri üzerinden borca batıklık bilançosu oluşturulmuştur.

\subsection{Borca Batıklık Bilançosunun Oluşturulması}

İIK m. 298/1 uyarınca komiser görevlendirilmesini müteakip borçlunun mevcudunun bir defterini yapar ve malların kıymetlerini takdir eder. Bu hüküm uyarınca borçlunun varlıklarının listesi temin edilerek malların kıymeti takdir edilmelidir. Şayet komiser heyetinde varlıkların kıymetini takdir edecek uzmanlıkta bir komiser yoksa bu konuda bilirkişiye başvurulmalıdır. Fakat komiser heyetinde teknik konularda uzman bir komiser var ise bu komiserin kendi uzmanlık konusuna giren varlıkların kıymetini tespit etmesi gerekmektedir. Kanun koyucu kıymet takdiri yapma görevini bizzat komisere yüklemiştir. Örnek uygulamada, kıymet takdirine tabi varlıklar, mesleki bilgi yönünden uygun bilirkişilerce kıymet takdirine tabi tutulmuştur. Bu süreçten sonra belirtilen ilkeler ve kıymet takdirlerini de içerecek şeklide oluşturulan borca batıklık bilançosu aşağıdaki gibi düzenlenmiştir.

Tablo 2. Borçlu Şirketin 30.09.2020 Tarihli Kaydi ve Rayici Bilançoları

\begin{tabular}{|c|c|c|c|}
\hline & $\begin{array}{c}31.03 .2020 \\
\text { Tarihli Kaydi } \\
\text { Değer Bilançosu }\end{array}$ & $\begin{array}{c}31.03 .2018 \\
\text { Tarihli Rayici } \\
\text { Değer Bilançosu }\end{array}$ & Değerleme Farkı \\
\hline \multicolumn{4}{|l|}{ I. DÖNEN VARLIKLAR } \\
\hline A. Hazır Değerler & $-3.870 .532,43$ & $-3.870 .532,43$ & 0,00 \\
\hline 1. Kasa & $76.684,68$ & $76.684,68$ & 0,00 \\
\hline 2. Alınan Çekler & $1.208 .435,13$ & $1.208 .435,13$ & 0,00 \\
\hline 3.Bankalar & $145.724,30$ & $145.724,30$ & 0,00 \\
\hline 4.Verilen Çekler ve Ödeme Emirleri(-) & $-5.301 .376,54$ & $-5.301 .376,54$ & 0,00 \\
\hline C. Ticari Alacaklar & $9.496 .971,56$ & $9.261 .522,56$ & $-235.449,00$ \\
\hline 1. Alicilar & 7.802.947,83 & 7.802.947,83 & 0,00 \\
\hline 2. Alacak Senetleri & $1.681 .423,73$ & $1.445 .974,73$ & $-235.449,00$ \\
\hline 6. Diğer Ticari Alacaklar & $12.600,00$ & $12.600,00$ & 0,00 \\
\hline D. Diğer Alacaklar & $1.564,81$ & $1.564,81$ & $\mathbf{0 , 0 0}$ \\
\hline 5. Diğer Çeşitli Alacaklar & $1.564,81$ & $1.564,81$ & 0,00 \\
\hline
\end{tabular}




\begin{tabular}{|c|c|c|c|}
\hline E. Stoklar & $7.566 .109,05$ & $5.441 .294,17$ & $-2.124 .814,88$ \\
\hline 1. İlk Madde Malzeme & $6.023 .550,37$ & $4.322 .500,00$ & $-1.701 .050,37$ \\
\hline 4. Ticari Mallar & $317.420,36$ & $239.453,00$ & $-77.967,36$ \\
\hline 5. Diğer Stoklar & $465.797,15$ & $120.000,00$ & $-345.797,15$ \\
\hline 7. Verilen Sipariş Avansları & $759.341,17$ & $759.341,17$ & 0,00 \\
\hline H. Diğer Dönen Varlılar & $303.826,15$ & $303.826,15$ & $\mathbf{0 , 0 0}$ \\
\hline 4. Peşin Ödenen Vergi ve Fonlar & $35.702,85$ & $35.702,85$ & 0,00 \\
\hline 5. İş Avansları & $268.123,30$ & $268.123,30$ & 0,00 \\
\hline DÖNEN VARLIK TOPLAMI & 13.497.939,14 & 11.137.675,26 & $-2.360 .263,88$ \\
\hline \multicolumn{4}{|l|}{ II. DURAN VARLIKLAR } \\
\hline D. Maddi Duran Varlıklar & $4.409 .142,19$ & $9.237 .000,00$ & 4.827.857,81 \\
\hline 1. Arazi ve Arsalar & $132.925,00$ & $585.000,00$ & $452.075,00$ \\
\hline 3. Binalar & $2.921 .952,22$ & $4.352 .000,00$ & $1.430 .047,78$ \\
\hline 4. Tesis Makine ve Cihazlar & $1.027 .872,40$ & $1.892 .000,00$ & $864.127,60$ \\
\hline 5. Taşıtlar & $1.623 .367,32$ & $2.154 .000,00$ & $530.632,68$ \\
\hline 6. Demirbaşlar & $343.514,70$ & $254.000,00$ & $-89.514,70$ \\
\hline 8. Birikmiş Amortismanlar & $-1.640 .489,45$ & & $1.640 .489,45$ \\
\hline E. Maddi Olmayan Duran Varlıklar & $17.485,72$ & $350.000,00$ & $332.514,28$ \\
\hline 1. Haklar & $11.534,12$ & \multirow{4}{*}{$350.000,00$} & \multirow{4}{*}{$332.514,28$} \\
\hline 3. Kuruluş ve Örgütlenme Giderleri & $1.683,17$ & & \\
\hline 5. Özel Maliyetler & $20.834,74$ & & \\
\hline 7.Birikmiş Amortismanlar & $-16.566,31$ & & \\
\hline DURAN VARLIK TOPLAMI & $4.426 .627,91$ & $9.587 .000,00$ & $5.160 .372,09$ \\
\hline AKTIF TOPLAM & 17.924.567,05 & $20.724 .675,26$ & $2.800 .108,21$ \\
\hline \multicolumn{4}{|l|}{ III.KISA VADELİ YABANCI KAYNAKLAR } \\
\hline A. Mali Borçlar & 3.992.673,28 & $3.992 .673,28$ & $\mathbf{0 , 0 0}$ \\
\hline 1. Banka Kredileri & $3.992 .673,28$ & $3.992 .673,28$ & 0,00 \\
\hline B. Ticari Borçlar & $4.470 .288,46$ & $4.463 .578,46$ & $-6.710,00$ \\
\hline 1. Saticilar & $4.072 .937,34$ & $4.072 .937,34$ & 0,00 \\
\hline 2. Borç senetleri & $48.000,00$ & $41.290,00$ & $-6.710,00$ \\
\hline 5. Diğer Ticari Borçlar & $349.351,12$ & $349.351,12$ & 0,00 \\
\hline C. Diğer Borçlar & $98.254,35$ & $98.254,35$ & $\mathbf{0 , 0 0}$ \\
\hline 4. Personele Borçlar & $98.254,35$ & $98.254,35$ & 0,00 \\
\hline D. AlınanAvanslar & $439.373,61$ & $439.373,61$ & $\mathbf{0 , 0 0}$ \\
\hline 1.Alınan Sipariş Avansları & $439.373,61$ & $439.373,61$ & 0,00 \\
\hline F. Ödenecek Vergi ve Diğer Yükümlülükler & $670.002,45$ & $825.400,00$ & $155.397,55$ \\
\hline 1. Ödenecek Vergi ve Fonlar & $397.737,44$ & \multirow{3}{*}{$825.400,00$} & $427.662,56$ \\
\hline 2. Ödenecek Sosyal Güvenlik Kesintileri & $183.116,65$ & & $-183.116,65$ \\
\hline 3.Vadesi Geçmiş Ertelenmiş veya Taksitlendirilmiş & $86.540,36$ & & $-86.540,36$ \\
\hline
\end{tabular}




\begin{tabular}{|c|c|c|c|}
\hline 4. Ödenecek Diğer Yükümlülükler & $2.608,00$ & & $-2.608,00$ \\
\hline KISA VADELİ YABANCI KAYNAK TOPLAMI & $9.670 .592,15$ & 9.819.279,70 & $148.687,55$ \\
\hline \multicolumn{4}{|l|}{ IV. UZUN VADELI YABANCI KAYNAKLAR } \\
\hline A. Mali Borçlar & $6.304 .026,03$ & $6.304 .026,03$ & 0,00 \\
\hline 1. Banka Kredileri & $6.304 .026,03$ & $6.304 .026,03$ & 0,00 \\
\hline B. Ticari Borçlar & $42.866,44$ & $42.866,44$ & $\mathbf{0 , 0 0}$ \\
\hline 5-Diğer Ticari Borçlar & $42.866,44$ & $42.866,44$ & 0,00 \\
\hline UZUN VADELİ YAB. KAYNAK TOPLAMI & $6.346 .892,47$ & $6.346 .892,47$ & 0,00 \\
\hline \multicolumn{4}{|l|}{ V. ÖZ KAYNAKLAR } \\
\hline A. Ödenmiş Sermaye & $3.400 .000,00$ & \multirow{11}{*}{$4.558 .503,09$} & \multirow{11}{*}{$2.651 .420,66$} \\
\hline 1 Sermaye & $3.400 .000,00$ & & \\
\hline C. Kar Yedekleri & $13.052,07$ & & \\
\hline 1. Yasal Yedekler & $13.052,07$ & & \\
\hline D. Geçmiş Yıl Karları & $962.435,39$ & & \\
\hline 1. Geçmiş Yı1 Karları & $962.435,39$ & & \\
\hline E. Geçmiş Yıllar Zararları & $-1.042 .385,85$ & & \\
\hline 1. Geçmiş Yıllar Zararları (-) & $-1.042 .385,85$ & & \\
\hline F. Dönem Net Karı (Zararı) & $-1.426 .019,18$ & & \\
\hline 1. Dönem Net Karı & 0 & & \\
\hline 2. Dönem Net Zararı & $-1.426 .019,18$ & & \\
\hline ÖZ KAYNAKLAR TOPLAMI & $1.907 .082,43$ & $4.558 .503,09$ & $2.651 .420,66$ \\
\hline PASIF TOPLAMI & $17.924 .567,05$ & 20.724.675,26 & $2.800 .108,21$ \\
\hline DEĞERLEME SONRASI ÖZKAYNAK ARTIŞI & & & $2.651 .420,66$ \\
\hline
\end{tabular}

Tablo 2'de yer alan alan kaydi bilanço verilerine göre borca batıklık bilançosunun oluşturulmasında göz önünde bulundurulan hususlar aşağıda başlıklar halinde özetlenmiştir.

- Hazır Değerler: İşletmenin Kasa Hesabında 76.684,68 TL, Alınan Çekler Hesabında 1.208.435,13 TL, Bankalar Hesabında 145.724,30 TL bulunmaktadır. Şirketin konkordato geçici mühlet sürecinden önce keşide ettiği çek tutarı 5.301.376,54 TL'dir. Yapılan incelemede işletmenin kasasında yabancı para bulunmadığı, kasa ve çek mevcudunun ise gerçeği yansıttığı tespit edilmiş bu sebeple söz konusu tutarlar nominal değeri üzerinden rayici değer bilançosuna alınmıştır.

- Ticari Alacaklar: İşletmenin ticari faaliyetlerinden dolayı 9.496.971,56 TL alacağ1 bulunmaktadır. Bu alacakların 7.802.947,83 TL'si senetsiz alacak, 1.681.423,73 TL'si senetli alacaklardan oluşmaktadır ve bu alacakların tahsil edilebilir olduğu tespit edilmiştir. Senetli alacaklara TCMB faizi üzerinden reeskont hesaplanmıştır. Yapılan hesaplamada bilanço tarihi itibari ile reeskont tutarı 235.449,00 TL olarak bulunmuştur. Reeskont tutarı ayrı bir kalem olarak gösterilmemiş ilgili ticari alacak tutarlarından mahsup edilerek bilançoya alınmıştır.

- Diğer Alacaklar: İşletmenin ticari ilişkide bulunmadığı çeşitli kişilerden senetli 1.564,81 TL alacağı bulunmaktadır. Bu alacakların tahsil edilebilir olduğu tespit edilmiştir. 
- Stoklar: İşletmenin stoklarının envanteri yapılmıştır. Yapılan envanterde işletmede, başka işletmelere ait konsinye stok kalemi olmadığı tespit edilmiştir. Ayrıca işletme envanterine kayıtlı konsinye olarak gönderilen stok tespit edilmemiştir. Bilanço tarihi itibari ile kaydi stok toplamı 7.566.109,05 TL'dir. Yapılan envanter çalışmasında ve bilirkişi tarafından yapılan değerlemede hammadde stok değerinin 4.322.500,00 TL, ticari mal stokunun 239.453,00 TL ve diğer stokların ise 120.000,00 TL olduğu tespit edilmiştir. Bu noktada şirkette fiktif stok kalemlerinin mevcut olduğu tespiti yapılmıştır. Bu durum faturasız mal satışlarından kaynaklanabileceği gibi çalınma vb. durumlardan da kaynaklanabilmektedir. Sonuç olarak stoklar hesap grubunda gerekli düzeltmeler yapıldıktan sonra stokların rayici değerinin 5,441,294,17 TL olduğu tespit edilmiştir.

- Diğer Dönen Varlıklar: Diğer dönen varlık kalemlerinin gerçeği yansıttı̆̆ı anlaşılmış olup toplam 303.826,15 TL kayıtlı değeri üzerinden bilançoda yer verilmiştir.

- Maddi Duran Varlıklar: İşletmenin arazi ve arsalarının defter değeri (kayıtlı değer) 132.925,00 TL'dir. Binalar hesabında kayıtlı bulunan taşınmazların defter değeri 2.921.952,22 TL'dir. İşletmenin taşınmazları üzerinde yapılan keşifte taşınmazlara iliş̧in olarak bilirkişi inşaat mühendisi tarafından yapılan değerlemede arazi ve arsaların değeri $585.000,00 \mathrm{TL}$, binaların değeri ise 4.352.000,00 TL olarak bulunmuştur. Makine mühendisi tarafindan yapılan değerlemede ise mevcut makine teçhizatın değeri 1.892.000 TL, taşıtların değeri 2.154.000,00 ve demirbaşların değeri ise 254.000,00 TL olarak tespit edilmiştir. Kıymet takdiri yapılmış olması sebebiyle maddi duran varlıklar için ayrılan amortisman tutarı bilanço dışı tutulmuştur.

- Maddi Olmayan Duran Varlıklar: Maddi olmayan duran varlıkların defter değeri 17.485,72 TL olduğu görülmektedir. Borca batıklığın doğru bir şekilde hesaplanabilmesi için marka değerlemesinin bilirkişi aracılığıyla değerlemesi yapılmıştır. Yapılan değerleme neticesinde marka değerinin 350.000,00 TL olduğu tespit edilmiştir. Bunun dışında diğer maddi olmayan duran varlık kalemlerinin tamamı bilanço dışı tutulmuştur.

- Banka Krediler (Kısa Vadeli): İşletmenin kısa vadeli kredi borçlarının kayıtlı değeri 3.992.673,28 TL'dir. Bu tutar şirketin geçici mühlet kararı aldığı tarih itibari ile banka vb finans kuruluşlarına olan borç tutarlarını içermektedir. Daha önce de belirtildiği gibi konkordato sürecinde kesin mühlet tarihine kadar adi borç tutarları üzerinde faiz işletilmesi mümkündür. Örnekte kesin mühlet sürecinden önceki dönemdeki borç batıklık değerlendirmesi yapıldığı için gerekli doğrulama yapıldıktan sonra geçici mühlet tarihindeki defter değeri dikkate alınmıştır.

- Ticari Borçlar: İşletmenin mal ve hizmet alımlarından kaynaklanan senetsiz borçlarının tutarı 4.439.113,64 TL, senetli borçlarının tutarı ise 48.000,00 TL'dir. Diğer ticari borç kapsamında sınıflandırılan borç tutarı ise 349.351,12 TL'dir. Borçlara ilişkin yapılan incelemede borçların belgelere dayalı olarak oluştuğu tespit edilmiştir. Senetli borçlar için yapılan hesaplamada reeskont tutarının $6.710,00 \mathrm{TL}$ olduğu anlaşılmış ve reeskont tutarı senetli borç tutarından düşülmüştür. Ticari borçlar, konkordato kapsamında olması sebebiyle borca batıklığın dışında konkordato nisabının oluşturulması açısından da son derece önemlidir. $\mathrm{Bu}$ sebeple, borçlu şirkete konkordato geçici mühletinin verildiği tarih itibariyle şirketin mevcut borç miktarının tespiti gerekmekte ve geçici mühlet sonrasında ortaya çıkan borçların yardımcı hesap düzeyinde "konkordato sürecinde ortaya çıkan borçlar" adı altında izlenmesi son derece 
faydalı olacaktır. Yukarıdaki örnekte olduğu gibi borçlu şirket, konkordato başvurusunu geçmiş dönem finansal tabloları ile yapmışsa, geçici mühlet tarihi itibariyle ara dönem finansal tablolarının çıkartılarak mevcut varlık ve borç durumunun tespitinin yapılması konkordato sürecinin sağlıklı işlemesi açısından büyük önem arz etmektedir.

- Diğer Borçlar: İşletmenin personeline 98.254,35 TL ödenmeyen ücretlerden kaynaklı borcunun bulunduğu ve bu borç için Ücret Garanti Fonu'na başvuruda bulunduğu tespit edilmiştir. Ücret Garanti Fonu Yönetmeliğine göre konkordato geçici mühleti verilen şirkette son 1 yıldır çalışmakta olan işçilerin 1 yıllık ücret alacakları Fon tarafindan ödenebilmektedir. Konkordato sürecinin tamamlanması halinde Fon tarafindan karşılanan ücretler, ilgili şirketten talep edilmektedir. Bu sebeple, söz konusu borcun varlığ 1 devam etmektedir.

- Alınan Avanslar: İşletmenin siparişe bağlanmış mal satışlarına ilişkin olarak müşterilerinden almış olduğu avansların tutarı 439.373,61 TL'dir.

- Ödenecek Vergi ve Diğer Yükümlülükler: İşletmenin ödenecek vergi ve yükümlülüklerinin defter değeri $670.002,45$ TL'dir. Yapılan borç sorgulamasında şirketin kamuya olan vergi ve sigorta prim borçlarının tamamının vadesinin geçmiş olduğu ve borç toplamının 825.400,00 TL olduğu tespit edilmiştir. Bu sebeple ilgili kalemde gerekli düzeltmeler yapılmıştır.

- Uzun Vadeli Banka Kredileri: İşletmenin banklardan almış olduğu uzun vadeli kredilerin defter değeri 6.304.026,03 TL'dir. Bankalarla yapılan mutabakat neticesinde tutarın gerçeği yansıttığı anlaşılmış ve tutar rayici değer bilançosuna aktarılmıştır.

- Uzun Vadeli Ticari Borçlar: İşletmenin uzun vadeli diğer ticari borç tutarı 42.866,44 TL olduğu ve gerçeği yansittığı görülmüştür.

- Öz Kaynaklar: Borçlu şirketin varlık ve yabancı kaynaklarının rayici değerlerinin belirlenmesinin ardından borca batıklığa esas öz varlık hesaplaması yapılmıştır. Muhasebenin temel denkliği esas alınarak yapılan hesaplamaya göre şirketin öz varlık toplamı 4.558.503,09 TL olarak hesaplanmıştır. Başka bir ifadeyle rayiç değerlere göre şirketin öz varlıklarında 2.651.420,66 TL artı̧ ortaya çıkmıştır.

\subsection{Borca Batıklığın Tespiti}

Yukarıda yapılan açıklamalar doğrultusunda borçlu şirketin 31.03.2020 tarihi itibariyle kaydi değer ile rayici değerler üzerinden borca batıklık değerlendirmesi aşağıdaki hesaplamalara göre yapılmış olup Tablo 3'te gösterilmiştir.

Borca Batıklık Oranı (BBO) : Aktif Toplamı / Yabancı Kaynak Toplamı

Öz Varlık Toplamı : Aktif Toplamı - Yabancı Kaynak Toplamı 
Tablo 3. Borçlu Şirketin Kaydi ve Rayici Değerler Üzerinden Borca Batıklık Durumu

\begin{tabular}{|l|r|r|}
\hline & \multicolumn{1}{|c|}{ KAYDI } & \multicolumn{1}{c|}{ RAYİCI } \\
\hline AKTIF & $\mathbf{1 7 . 9 2 4 . 5 6 7 , 0 5}$ & $\mathbf{2 0 . 7 2 4 . 6 7 5 , 2 6}$ \\
\hline DÖNEN VARLIKLAR & $13.497 .939,14$ & $11.137 .675,26$ \\
\hline DURAN VARLIKLAR & $4.426 .627,91$ & $9.587 .000,00$ \\
\hline YABANCI KAYNAKLAR & $\mathbf{1 6 . 0 1 7 . 4 8 4 , 6 2}$ & $\mathbf{1 6 . 1 6 6 . 1 7 2 , 1 7}$ \\
\hline KISA VAD. YAB. KAY. & $9.670 .592,15$ & $9.819 .279,70$ \\
\hline UZUN VAD. YAB. KAY. & $6.346 .892,47$ & $6.346 .892,47$ \\
\hline ÖZ VARLIK TOPLAMI & $\mathbf{1 . 9 0 7 . 0 8 2 , 4 3}$ & $\mathbf{4 . 5 5 8 . 5 0 3 , 0 9}$ \\
\hline BORCA BATIKLIK ORANI & $\mathbf{1 , 1 2}(\mathbf{\%} \mathbf{1 2 0})$ & $\mathbf{1 , 2 8}(\mathbf{1 2 8})$ \\
\hline
\end{tabular}

Konkordato talebinde bulunan şirketin bilirkişi incelemesi neticesinde oluşan kıymet takdirleri, şirketin 31.03.2020 tarihli kaydi değer bilançosuna işlenmiş ve rayici değerleri içeren bilanço kalemleri üzerinden öz varlık ve borca batıklık tespiti yapılmıştır. Rayici değerler üzerinden yapılan tespitte 31.03.2020 tarihi itibari ile 4.226.463,34 TL öz varlık hesaplanmış ve $\% 128$ oranında borca batık olmadığı tespit edilmiştir. Bir başka ifade ile şirket aktiflerinin rayiç değerler üzerinden şirket borçlarını karşılamaya yettiği tespit edilmiş̧ir. Bu durumda borca batıklık açısından konkordato talebinin reddi halinde mahkeme tarafından şirketin iflası açılmayacaktır.

\section{SONUÇ}

İflasın ertelenmesi müessesenin kaldırılması ile birlikte gerek IIIK gerekse TTK' da yapılan değişiklikle borçlarını vadesinden ödeyemeyen veya ödeyememe tehlikesi altında bulunan işletmelerin borçluları ile anlaşma yapmak sureti ile muhtemel bir iflastan kurtulmasını sağlayan konkordato müessesi Türk hukuk sisteminde işlerlik kazanmıştır. Borca batıklık, TTK ve İIK' da iflas nedeni olarak düzenlenmiş ise de yine aynı kanunlarda bir konkordato nedeni olarak da düzenlendiği görülmektedir. Konkordatoya ilişkin düzenlemelerde iflas erteleme müessesinden farklı olarak borca batıklık bir şart olarak getirilmemiştir. Bu noktada konkordato ön projesinden başlamak üzere geçici mühlet talebinin reddi, kesin mühlet talebinin reddi ve konkordato tasdik talebinin reddi durumlarında, mahkeme tarafından şirketin iflasının açılmasının şartı şirketin borca batık olması durumudur. Her ne kadar konkordato başvurusunda bulunan işletmeler, başvuru esnasında Mahkemeye sundukları ön projelerine aktiflerin muhtemel satış fiyatları üzerinden hazırlanan bilançolarını ekleseler de bu bilançonun borca batıklığa esas olmak üzere komiser heyeti tarafından ya da Mahkemece verilecek karara göre bilirkişiler tarafından hazırlanması gerekmektedir.

Borca batıklık bilançosunun oluşturulmasında öncelikle dikkat edilmesi gerekenhusus, bu bilançonun oluşturulma zamanıdır. Kanaatimize göre rayici değer bilançosunun dolayısıyla konkordato sürecinde kıymet takdirlerinin geçici mühlet süreci içerisinde yapılması gerekmektedir. Çünkü, borçlu şirketin kesin mühlete geçememe, başka bir ifadeyle konkordato talebinin geçici mühletin sonunda reddedilmesi ihtimali her zaman bulunmaktadır. Bu sebeple, kıymet takdirinin geçici mühlet içerisinde yapılması, hatta 3 aylık sürede yapılamaması durumunda 2 aylık ek sürenin mahkemeden talep edilmesinin faydalı olacağı düşünülmektedir. 
Rayici değer bilançosunun oluşturulmasında dikkat edilmesi gereken bir diğer husus ise bilanço kalemlerinin hangi kriterlere göre değerlendirilmesi gerektiği konusudur. Bu noktada, stoklar, maddi ve maddi olmayan duran varlıklar gibi değerlerinin yeniden belirlenmesi gereken varlık türlerinin rayici değerlerinin, kıymet takdiri yoluyla belirlenmesi gerekmektedir. Bunlar dışında kalan varlıkların ise gelecek aylara/yıllara ait giderler gibi muhasebe tekniği açısından varlık olarak nitelendirilen ancak, gerçekte varlık olarak nitelendirilebilmesi mümkün olmayan varlık unsurlarının bilançodan arındırılması gerekmektedir. Uygulamada, işletmelerin ödenmemiş sigorta primlerini gider kaydetmeyerek, genel kabul görmüş muhasebe ilkelerine aykırı olarak gelecek aylara/yıllara ait giderler hesaplarıyla ilişkilendirdikleri görülmektedir. Böyle bir durumda hem aktifler olduğundan fazla gösterilmekte, hem de gider yazılmayan tutar kadar şirketin kârlılığına etki edildiği görülmektedir.

Borca batıklığın tespitinde dikkat edilmesi gereken başka bir varlık kalemi ise avanslardır. Uygulamada, faturasız alışlar neticesinde yapılan ödemelerin genel kabul görmüş muhasebe ilkelerine aykırı olarak bu hesaplara kaydedilmesi, sıklıkla karşılaşılan bir durumdur. Böyle bir durumda gerçekte varlık unsuru olarak nitelendirilemeyecek yapay bir varlık oluşturulmakta ve bu yapay varlığın rayiç değer bilançosundan arındırılması gerekmektedir. Benzer bir şekilde, şirketlerin muhtemel bir iflasın önüne geçmek amacı fiktif alacaklar oluşturması da zaman zaman karşılaşılan bir durumdur. Bu durumda, sondajlama yöntemiyle alacakların varlığının kontrol edilmesi gerektiği düşünülmektedir.

Uygulamada karşılaşılan başka bir durum ise şirketlerin varlıklarının yanı sıra borçlarına da yapay bir takım ilaveler yapmasıdır. Bu ilavelerin sebebi ise konkordato oylamasında gerçekte olmayan borç tutarları için alacaklılardan kabul oyu alınarak konkordatonun tasdikini sağlamaktır. Ancak, böyle bir durumun varlığının tespitinin oldukça güç olduğu düşünülmektedir.

Borca batıklık bilançosunun oluşturulmasında, işletmenin gerçek değerler üzerinden tespiti yapılan varlıkları ile yine gerçek değerler üzerinden tespiti yapılmış borçlarının ödenmesi halinde kalan varlık tutarının tespit edilmesi gerekmektedir. Bir başka deyişle kalan varlık, işletmenin 3. kişilere olan yükümlülüklerini yerine getirdikten sonra işletmede kalan özvarlık tutarının belirlenmesini ifade etmektedir. Bu nedenle, borca batıklık bilançosunda yer alacak varlık kalemleri ve borç kalemleri borca batıklık bilançosunun oluşturulduğu tarihte piyasa şartlarında oluşan tutarlar üzerinden bilançoda gösterilmelidir. Mali yapısı bozulan işletmelerin ticari faaliyetlerine devam etmesini sağlamak amacına yönelik olarak hukuk sistemimizde yer alan konkordato müessesesi sonuçları itibari ile ekonomik ve sosyal etkiye sahiptir. Konkordato talebinde bulunan borçlu işletme, alacaklılar, kamu ve işletme personeli konkordatoya ilişkin sonuçlardan en çok etkilenen taraflar olmaktadır. Konkordato sürecinin belirli aşamalarında mahkeme tarafından konkordato talebinin reddi halinde mahkeme tarafından şirketin borca batıklığının tespiti önem arz etmektedir. Zira şirketin borca batıklığ durumu mahkeme tarafından iflasın açılması ile sonucunu doğurmaktadır. Bu nedenle iflas gibi ağır sonuçları olan bir karara temel oluşturan borca batıklık bilançosunun oluşturulması gerek mali konularla ilgili komisere gerekse muhasebe bilirkişisine ağır sorumluluklar yüklemektedir. Borca batıklık bilançosunun oluşturulması noktasında komiser ve mali bilirkişiler konkordato talebinde bulunan şirketin borca batıklık bilançosunu oluşturma noktasında genel kabul görmüş muhasebe ilke ve kaidelerine, muhasebe standartlarına, ticaret kanuna ve vergi kanunlarına uygun olarak mesleki tecrübe ve mesleki özen prensiplerine uygun olarak hareket etmek zorundadirlar. 


\section{KAYNAKLAR}

Akdeniz, Murat - Kayıhan, Şaban (2019), Konkordato Hukuku El Kitab1, 13. Bask1, Umuttepe Yayınları, İstanbul.

Akil, Cenk (2019), Sorularla Adi Konkordato, Adalet Yayınevi, Ankara.

Altay, Adem (2016), Borca Batıklık Ve İflasın Ertelenmesi, Gazi Kitabevi, Ankara. Apalı, İbrahim (2018), "Vergi Usul Kanunu Açısından Konkordato İlanı Kapsamında Vazgeçilen Alacakların Değerlendirilmesi Ve Muhasebeleştirilmesi”, Mali Çözüm Dergisi, 150, ss. 211-219.

Bilen, Cumhur İnan - Selin, Güler (2019), “Konkordato Ve Alacakların Akıbeti”, Vergi Dünyası Dergisi, 38 (449), ss. 81-97.

Bitlisli, Ferhat - Yılmaz, Tayfun (2016), "İflasın Ertelenmesinde Borca Batıklık Bilançosunun Oluşturulması: Bir Uygulama”, Mehmet Akif Ersoy Üniversitesi Sosyal Bilimler Enstitüsü Dergisi, 8 (15), ss.207-223.

Budak, Ali Cem - Kale, Serdar (2019), Konkordato Komiserinin Kontrol Listesi, Adalet Yayınevi, Ankara.

Çukacı, Yusuf Cahit (2019), Konkordato, Ekin Basım Yayın Dağıtım, Bursa.

Demir, Gülay - Teker, Suat (2019), “İflas Erteleme Ve Konkordato”, Press Academia Procedia 9 (1), ss. 278-284.

Ermenek, İbrahim - Özdemir, Ufuk - Özalp, Ali Rıza (2020), "Bir Konkordato Nedeni Olarak Borca Batıklığın Tespiti Ve Borca Batıklık Halinin Konkordato Sürecindeki Etkileri”, Çankaya Üniversitesi Hukuk Fakültesi Dergisi, 5 (1-2), ss. 1351-1381.

Eroğlu, Orhan (2018), Uygulamada Konkordato, Seçkin Yayınları, 1. Basım. Ankara.

İcra Ve İflas Kanunu, https://www.mevzuat.gov.tr/mevzuatmetin/1.3.2004.pdf, (04.10.2020).

Kale, Serdar (2018), “7101 Sayılı İcra ve İflas Kanununda Değişiklik Yapılmasına Dair Kanun Çerçevesinde İflas Dişı Adi Konkordato", İstanbul Medipol Üniversitesi Hukuk Fakültesi Dergisi 5 (1), 213-269.

Karacan, Sami (2018), “Konkordato Finansal Krizde Çözüm Mü?”, Uluslararası Turizm, İşletme Ekonomi Dergisi, 2 (2), ss. 97-112.

Kayar, İsmail (2012), “Yeni Ttk’ya Göre Anonim Şirkette Sermaye Kaybı Ve Borca Batıklığın Tespiti Ve Sonuçları" Marmara Üniversitesi Hukuk Fakültesi Dergisi, 18 (2), ss. 643-658.

Keleş, Dursun (2017), "Borca Batık İşletmelerin İflasının Ertelenmesinde İyileştirme Projesinin Önemi: Muhasebe Bakış Açısıyla Bir Değerlendirme”, Muhasebe Ve Vergi Uygulamaları Dergisi, 10 (2), ss. 185.208. 
Oruç, Murat (2018), Konkordato Uygulama Rehberi, On İki Levha Yayıncılık, İstanbul.

Özbilen, Zekeriya Başar (2015), “Anonim Şirketlerde Borca Batıklığın Tespiti Ve Hukuki Sonuçları", https://www.xing.com/communities/posts/anonim-sirketlerde-borcabatikligin-tespiti-ve-hukuki-sonuclari-1010279718, (05.10.2020).

Özdemir, Murat (2019), “Konkordato Talebinde Adli Muhasebe Desteği”, Balkan Ve Yakın Doğu Sosyal Bilimler Dergisi, 5 (2), ss. 16-22.

Şengöz, Yunus - Ayaz, Ahmet (2020), İcra Ve İflas Hukukunda Konkordato Ve Konkordato Komiserliği, Adalet Yayınevi, Ankara.

Türk Dil Kurumu, https://sozluk.gov.tr/, (05.10.2020).

Türk Ticaret Kanunu, https://www.mevzuat.gov.tr/mevzuatmetin/1.5.6102.pdf, (04.10.2020).

Türk, Ahmet (2004), "Sermaye Ortaklıklarının Ve Kooperatiflerin Borca Batıklık Nedeniyle İflâsı ve İflâsın Ertelenmesi Konusunda İcra Ve İflâs Kanunu'nda Yapılan Son Değişikliklerin Değerlendirilmesi Ve Öneriler”, Dokuz Eylül Üniversitesi Hukuk Fakültesi Dergisi, 6 (1), ss. 295-334.

Yılmaz, Berna Burcu (2009), "İflasın Tespiti Ve Ertelenmesi Yönünden Borca Batıklık Bilançosu Ve İyileştirme Projesi Üzerine Bir İnceleme”, Marmara Üniversitesi Sosyal Bilimler Enstitüsü, Doktora Tezi, İstanbul. 